\title{
Recovery and Partitioning of Nitrogen from Early Spring and Midsummer Applications to Pecan Trees
}

\author{
Michael W. Smith ${ }^{1,2}$ \\ Department of Horticulture \& Landscape Architecture, Oklahoma State University, Stillwater, \\ OK 74078 \\ Bruce W. Wood \\ U.S. Department of Agriculture, Agricultural Research Service, Southeastern Fruit and Tree Nut \\ Research Laboratory, Byron, GA 31008 \\ William R. Raun ${ }^{1}$ \\ Department of Plant and Soil Sciences, Oklahoma State University, Stillwater, OK 74078
}

\begin{abstract}
AdDitional INDEX words. Carya illinoinensis, ${ }^{15} \mathrm{~N}$-enriched fertilizer, application time, absorption, woody species
Abstract. Effective nitrogen (N) management promotes consistent and abundant pecan [Carya illinoinensis (Wangenh.) C. Koch] production while minimizing waste. Recovery and partitioning characteristics of $\mathrm{N}$ potentially affects $\mathrm{N}$ management decisions; for this reason, we report certain $\mathrm{N}$ characteristics exhibited by trees in a bearing 'Pawnee' orchard. Nitrogen was applied prebudbreak (PBB) as a single 10 Mar. application at $1.689 \mathrm{~g} \cdot \mathrm{cm}^{-2} \mathrm{cross}^{-}$ sectional trunk area or a split application in Mar. (70\%) followed by a midsummer application during rapid fruit development (RFD) on 28 July (30\%) (i.e., PBB + RFD) using ${ }^{15} \mathrm{~N}$-enriched fertilizer. Recovery of $\mathrm{N}$ by trees the first year was $7.2 \%$ from the PBB application and $11 \%$ from the RFD portion of the split application. Nitrogen application was $210 \%$ larger at PBB (Mar.) than at RFD (July), resulting in $118 \%$ more $N$ absorbed. At harvest in November, fruit contained $41 \%$ and $36 \%$ of total $N$ recovered during the first year from the PBB and RFD treatments, respectively. About $3 \%$ of the total fruit $\mathrm{N}$ was derived from fertilizer (NDF) absorption during the current year. Recovery was $12 \%$ for the PBB treatment and $19 \%$ for the RFD treatment by the end of the second growing season, with $93 \%$ more $N$ absorbed from the $P B B$ application. Nitrogen recovered from the $P B B$ application increased $\approx 50 \%$ while trees were dormant, but there was little change in $\mathrm{N}$ recovery when applied during RFD. During the year of application, NDF was similar in shuck, shell, and kernel tissue when ${ }^{15} \mathrm{~N}$-enriched fertilizer was applied PBB. When applied at RFD, more NDF was in the kernel than the shuck and shell, indicating rapid absorption and transport to the fruit, especially to the developing kernel. In both treatments, most fruit $\mathrm{N}$ was derived from tree storage reserves. In the second year, NDF was highest in shucks and lowest in kernels for the PBB application; thus, N enrichment from the previous year was being depleted. In contrast, NDF was higher in kernels than shucks and shells when ${ }^{15} \mathrm{~N}$ enriched fertilizer was applied during RFD the previous year, indicating that $N$ applied during RFD the previous July was being absorbed in the latter part of the subsequent growing season. This study demonstrates that pecan trees maintained with adequate $N$ nutrition derived the majority of $N$ used for annual parts from stored $N$ pools, although applied $\mathbf{N}$ was also rapidly absorbed and transported to $\mathrm{N}$ sinks. Dependence on endogenous $\mathrm{N}$ pools explains why pecans usually require at least 2 years to respond when $N$ is withheld from well-managed trees. These results emphasize the importance of maintaining an annual $\mathrm{N}$ fertility program for current and future production.
\end{abstract}

Adequate nitrogen nutrition is among a cadre of management practices necessary to maintain profitable and productive pecan orchards (Smith et al., 1985; Taylor, 1930; Worley, 1974, 1990). Nitrogen is applied in many orchards either as a single early spring application shortly before budbreak or as two applications split between about budbreak and late canopy development (May or June). Nitrogen was depleted by large crop loads in pistachio (Pistacia vera $\mathrm{L}$.), a condition possibly contributing to alternate bearing (Brown et al., 1995; Rosecrance et al., 1998; Weinbaum et al., 1994). Stored tree $\mathrm{N}$ during the winter correlated with pistachio crop loads in the

Received for publication 6 Apr. 2007. Accepted for publication 11 Aug. 2007. Approved for publication by the Oklahoma Agricultural Experiment Station. Funding for this study was provided by the Oklahoma Agricultural Experiment Station, U.S. Dept. of Agriculture-Agriculture Research Service, Samuel Roberts Noble Foundation, Savage Equipment Company, and the Oklahoma Pecan Growers' Association.

${ }^{1}$ Regents Professor.

${ }^{2}$ Corresponding author. E-mail: mike.smith@okstate.edu. subsequent growing season (Picchioni et al., 1997; Rosecrance et al., 1996). Most $\mathrm{N}$ used during the initial spring canopy growth flush and flowering in pistachio (Weinbaum et al., 1994) and walnut (Juglans regia L.) (Weinbaum and Van Kessel, 1998) was from storage pools.

Some have conjectured that heavy crop loads in pecan potentially create a critical endogenous $\mathrm{N}$ shortage that affects alternate bearing (Goff et al., 2001; Kraimer et al., 2004; Wood, 2001). Stored $N$ was preferentially used in the spring (AcuñaMaldonado et al., 2003; Kraimer et al., 2001, 2004; Rey et al., 2006), followed by rapid $\mathrm{N}$ absorption after the endogenous pool was nearly depleted (Acuña-Maldonado et al., 2003). The amounts of stored vs. absorbed $\mathrm{N}$ in the spring was inversely related (Acuña-Maldonado et al., 2003). Two studies, performed in flood-irrigated New Mexico orchards, reported $\mathrm{N}$ applied while pecan fruit were rapidly developing (Aug. or Sept.) was quickly absorbed by trees, substantially increasing stored N (Kraimer et al., 2004; Rey et al., 2006). By contrast, an Oklahoma study found little $\mathrm{N}$ absorption before autumn leaf 
fall when $\mathrm{N}$ was applied in October, near fruit maturity, although substantial $\mathrm{N}$ was absorbed during the dormant season (Acuña-Maldonado et al., 2003).

Cultural conditions differ substantially between southwestern, south-central, and southeastern United States' pecan production regions. Differences include soil, rainfall, and light characteristics; canopy management; irrigation characteristics; and nut production. In the southwestern United States, flood irrigation is typical, trees are mechanically pruned, orchard floors are clean-cultivated, sunlight intensity is greater, and there are fewer cloudy days. In the south-central United States, most orchards are not irrigated, and those with irrigation use pressurized systems, tree crowding is controlled by tree removal, and orchard floors are maintained with either vegetation or a combination of vegetation-covered aisles and vegetation-free zones in the tree row. Rainfall in Oklahoma rarely exceeds evapotranspiration; thus, $\mathrm{N}$ is seldom lost to deep percolation, except during the winter. Flood-irrigated orchards, such as most southwestern United States' orchards, may experience substantial N loss into the groundwater (Kraimer et al., 2001). These are only a few of the regional differences that potentially influence efficient $\mathrm{N}$ management. This study determines $\mathrm{N}$ recovery from a single early spring $\mathrm{N}$ application and from two applications split between early spring and midsummer during fruit development, thus providing expanded insight into the $\mathrm{N}$ uptake characteristics of trees in pecan orchards.

\section{Materials and Methods}

The study was conducted in south-central Oklahoma (Hauani Creek Ranch near Madill). Study trees were 'Pawnee' scions grafted onto native pecan rootstocks. The native sapling density had been reduced to approximate a $10.7 \times 10.7 \mathrm{~m}$ spacing before grafting. Trees were $\approx 13$ years old at the beginning of the study and ranged in size from 16.1 to $19.6 \mathrm{~cm}$ in trunk diameter (measured $1.4 \mathrm{~m}$ above the ground at the beginning of the study).

The orchard soil was a Madill fine sandy loam (coarseloamy, mixed, active, nonacid, thermic Typic Udifluvents) with soil pH 6.2 and organic matter $0.44 \%$ at $0-15 \mathrm{~cm}$ depth and soil $\mathrm{pH} 7.2$ and organic matter $0.37 \%$ at $15-30 \mathrm{~cm}$ depth. The orchard was not irrigated, and rainfall at this site averaged 1053 $\mathrm{mm}$ annually. In 2003, rainfall from Jan. through Dec. was 656 $\mathrm{mm}$, and in 2004 rainfall totalled $1118 \mathrm{~mm}$ (Fig. 1). Rainfall deficit or excess was calculated to determine the likelihood of $\mathrm{N}$ leaching into the groundwater. Evapotranspiration (ET) was calculated using class A pan evaporation and coefficients developed for pecan (Stein and Worthington, 1997) during May through Sept., and ET estimates for a cool-season grass during the other months (Kizer et al., 2005). Evapotranspiration was subtracted from rainfall to determine deficiencies or excesses and summarized by week (Fig. 2). The entire orchard floor was maintained vegetation-free during the growing season with repeated glyphosate applications. Pest management followed standard recommendations for a commercial orchard in Oklahoma (von Broembsen and Mulder, 2005).

Treatments. Nitrogen was hand-broadcast on the soil surface within the tree drip-lines at $1.689 \mathrm{~g} \cdot \mathrm{cm}^{-2}$ cross-sectional trunk area, measured $1.4 \mathrm{~m}$ above the ground. Nitrogen was applied as either a single early spring prebudbreak (PBB) application on 10 Mar. 2003 or in two applications with $70 \%$ applied on 10 Mar. and the remaining 30\% applied midsummer during rapid fruit development on 28 July 2003. An untreated

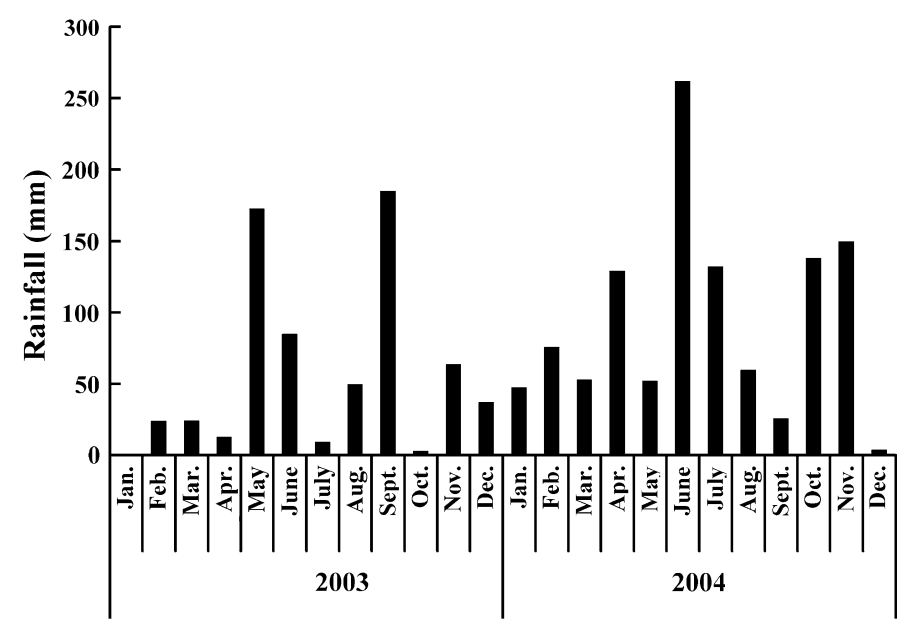

Fig. 1. Rainfall summarized by month during 2003 and 2004 near Madill, OK.

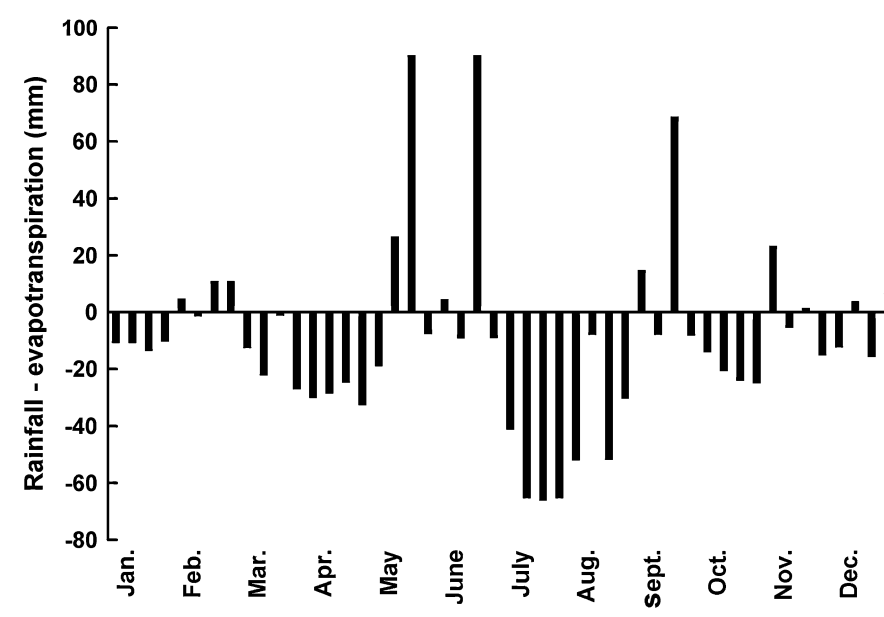

Fig. 2. Summary by week of the difference between rainfall and evapotranspiration near Madill, OK, using calculations for pecan during May through Sept. and a cool-season grass during the other months in 2003.

control was also included to determine ${ }^{15} \mathrm{~N}$ natural abundance. Thirty percent of the single PBB treatment was from a 5 atom $\%$ ${ }^{15} \mathrm{~N}$-enriched $\mathrm{NH}_{4}{ }^{15} \mathrm{NO}_{3}$, and the remainder was commercial $\mathrm{NH}_{4} \mathrm{NO}_{3}$. In the split application, commercial $\mathrm{N}$, as $\mathrm{NH}_{4} \mathrm{NO}_{3}$, was used at PBB (10 Mar.), followed by 5 atom $\%{ }^{15} \mathrm{~N}$-enriched $\mathrm{NH}_{4}{ }^{15} \mathrm{NO}_{3}$ applied at RFD on 28 July. Thus, trees received the same amount of ${ }^{15} \mathrm{~N}$-enriched fertilizer relative to their size, but it was applied either in Mar. as part of a single application or in July as the second part of a split application, resulting in different ${ }^{15} \mathrm{~N}$-enrichment concentrations for the two treatments (i.e., 1.5 atom \% for PBB vs. 5 atom \% for RFD).

Fertilizer was incorporated by natural rainfall or irrigation. Following fertilizer application at PBB on 10 Mar. 2003, $3 \mathrm{~mm}$ of rain was received 11 Mar., followed by $1 \mathrm{~mm}$ on 13 March and $17 \mathrm{~mm}$ on 18 March (Fig. 1). Immediately following the RFD application of $\mathrm{N}$ on 28 July, $6 \mathrm{~mm}$ of water was applied with movable set-sprinkler irrigation. In 2004, trees were fertilized with $\mathrm{N}$ rates and at application dates equivalent to the treatments using only commercial $\mathrm{NH}_{4} \mathrm{NO}_{3}$.

The 2003 crop season was expected to be a relatively heavy (i.e., on) crop year; however, abnormally low temperatures $\left(0,-2.8\right.$, and $-1.1{ }^{\circ} \mathrm{C}$ on $8-10$ Apr.) killed expanding shoots $(2-5 \mathrm{~cm}$ long) and catkins. New growth, pistillate flowers, and 
catkins developed from secondary buds, but the resulting crop was small (i.e., off, $4 \mathrm{~kg} / \mathrm{tree}$ ).

Treatments were structured in a randomized complete block design with blocking according to trunk diameter. Each treatment was replicated five times using single-tree plots.

SAMPLE TIMES AND TISSUES SAMPLED. Nitrogen-treated and untreated control trees (for natural abundance ${ }^{15} \mathrm{~N}$ determination) were sampled during the first growing season at the end of rapid shoot and leaf expansion (4 June 2003), before the second N application while fruit were rapidly expanding (28 July 2003), and at $50 \%$ defoliation (3 Nov. 2003). Trees were again sampled during the second growing season (2004) at bud swell (29 Mar.) and at the development states reflected in the first season's sampling (18 June, 28 July, and 5 Nov. 2004). Tissues sampled included fruit, leaves, current-season shoots, inner bark (phloem and associated tissue, dead outer bark excluded), wood, and roots $<1 \mathrm{~cm}$ diameter and $\geq 1 \mathrm{~cm}$ in diameter. Fruit samples ranged from 50 to 20 fruit per tree depending on fruit size. Entire fruit were analyzed for $\mathrm{N}$, except those sampled in Nov. were divided into shuck (involucre), shell (pericarp), and kernel (cotyledon) for analysis. About 50 compound leaves were collected per tree by removing all leaves on individual shoots. The entire compound leaf was used for analysis. Ten current-season shoots were collected per tree during each sample time. Bark and wood samples were processed by first removing the dead outer bark. A spade bit equipped drill was then used to bore several holes to the center of the trunk while collecting bark and wood. Bark was then visually separated from the wood. Root samples were collected by excavating an area $\approx 1 \mathrm{~m}$ deep by $0.3 \mathrm{~m}$ wide and $1.5 \mathrm{~m}$ long perpendicular to the trunk under the drip line with a backhoe. Root samples were separated into those $<1 \mathrm{~cm}$ diameter and $\geq 1 \mathrm{~cm}$ in diameter for analysis. Samples were dried at $70{ }^{\circ} \mathrm{C}$ and then ground to pass through a 20-mesh screen.

Sample ANALYsis. Samples were initially analyzed in duplicate for total $\mathrm{N}$ and ${ }^{15} \mathrm{~N}$ using a stable isotope mass spectrometer (Isotope Laboratories, Los Alamos, NM) and then analyzed for total $\mathrm{N}$ by the macro-Kjeldahl method (Horowitz, 1980) at Oklahoma State University. Samples were therefore analyzed in triplicate for total $\mathrm{N}$, and if concentrations differed by $0.05 \%$ or more, they were reanalyzed.

Nitrogen AND ReCOVERY ESTIMATES. Estimations of biomass, using trunk diameter at $1.4 \mathrm{~m}$ above the ground, for tree components were calculated using allometric equations developed for pecan (Smith and Wood, 2006). Total N in each component was calculated by multiplying estimated weight by $\mathrm{N}$ concentration, except for fruit. Fruit were harvested in Nov. and weighed. Weights of shucks, shells, and kernels were determined from duplicate 20 -fruit samples per tree. The number of fruit per tree was calculated based on tree yield and fruit weight. Weight of fruit per tree at other sample times was calculated by multiplying the fruit per tree by the average fruit weight during each sample time. Total $\mathrm{N}$ in the fruit was then estimated from those fruit weights.

Tissue recoveries were calculated with the following equation (Rey et al., 2006):

$$
\begin{aligned}
\text { Percent recovery }= & (\text { biomass })(\text { total } \mathrm{N} \text { concentration }) \\
& \left({ }^{15} \mathrm{~N}_{\text {sample }}-{ }^{15} \mathrm{~N}_{\mathrm{BG}}\right)(100)\left(1 /{ }^{15} \mathrm{~N}_{\text {applied }}\right)
\end{aligned}
$$

where biomass (in grams) was determined for each component as described above; total $\mathrm{N}$ concentration was bulk
$\mathrm{N}$ concentration of each tree component; ${ }^{15} \mathrm{~N}_{\text {sample }}$ was the atom $\%$ in the sample tissue; ${ }^{15} \mathrm{~N}_{\mathrm{BG}}$ was the atom $\%$ in the control tissue (0.369 atom \%); and ${ }^{15} \mathrm{~N}_{\text {applied }}$ was the number of grams applied per tree. Total tree recovery was determined by summing the tree component recoveries.

Nitrogen derived from ${ }^{15} \mathrm{~N}$-enriched fertilizer (NDF) in the fruit was calculated using the following equation (Allen et al., 2004):

$$
\operatorname{NDF}(\%)=100(a-b) /(c-d),
$$

where $a$ is the atom $\%{ }^{15} \mathrm{~N}$ abundance in plant tissue; $b$ the atom $\%{ }^{15} \mathrm{~N}$ abundance in control tissue (0.369 atom $\left.\%\right) ; c$ the atom $\%$ ${ }^{15} \mathrm{~N}$ abundance of fertilizer; and $d$ the natural atom $\%{ }^{15} \mathrm{~N}$ abundance $(0.366$ atom \%).

Data were analyzed using analysis of variance. Analysis was by tissue type with sample date nested within nitrogen treatment. Treatments were declared different when the probability of equal means was $5 \%$ or less. Means were separated using the protected least significant difference. Data are presented graphically with SE.

\section{Results and Discussion}

The difference between rainfall and evapotranspiration suggests that loss of $\mathrm{N}$ by deep percolation was unlikely (Fig. 2). Rainfall occasionally exceeded ET during the summer, but this appeared insufficient to cause leaching losses. First, large amounts of rainfall usually result in some runoff rather than all entering the soil. Calculations used for the differences in rainfall and ET assumed rainfall was $100 \%$ efficient, which is unlikely. Second, the water-holding capacity of a Madill fine sandy loam is about $125 \mathrm{~mm} / \mathrm{m}$ with a depth to groundwater of $2.5 \mathrm{~m}$ (Smith and Wood, 2006). Because the cumulative water deficit in 2003 exceeded surplus rainfall, it was likely that water entering the soil was held rather than leaching through the soil profile to the groundwater.

Recovery of applied ${ }^{15} \mathrm{~N}$-enriched fertilizer was evident no later than $85 \mathrm{~d}$ after the PBB application (Fig. 3). About $4.5 \%$ of the PBB applied $\mathrm{N}$ was recovered by June of the first year. The leaves had $\approx 67 \%$ of the $N$ recovered, while $33 \%$ was located in the perennial parts, and a tiny fraction had been transported to fruit. Four percent of the June leaf $\mathrm{N}$ was derived from PBBapplied fertilizer (Fig. 4). Recovery of applied $\mathrm{N}$ was essentially unchanged in July of the first year (Fig. 3), and NDF had decreased to $\approx 3 \%$ of leaf $\mathrm{N}$ (Fig. 4), indicating that stored $\mathrm{N}$ was being mobilized faster than additional $\mathrm{N}$ was being absorbed from the soil. During June and July, the fruit were small and accounted for little of the tree's total $\mathrm{N}$ content. The NDF was similar in the fruit (Fig. 5) and leaves (Fig. 4), indicating that both annual organs were supported by $\mathrm{N}$ derived from remobilization and absorption in similar proportions.

Enriched $\mathrm{N}$ recovery was greater in the roots than in trunk and branches during June $(0.8 \%$ vs. $0.6 \%)$ and July $(1.1 \%$ vs. $0.8 \%$ ) of the first year (Fig. 3). NDF was greater in the currentseason shoots than other perennial parts (Fig. 6). The largest percentage of NDF was in the leaves and fruit (Figs. 4 and 5).

By November of the first year, trees recovered $7.2 \%$ of ${ }^{15} \mathrm{~N}$ applied PBB (Fig. 3), whereas $11 \%$ of ${ }^{15} \mathrm{~N}$ was recovered from the RFD application. Trees absorbed $118 \%$ more $\mathrm{N}$ from the PBB treatment than from RFD application $(210 \%$ more $\mathrm{N}$ was applied PBB in March than at RFD in July). At nut harvest in 


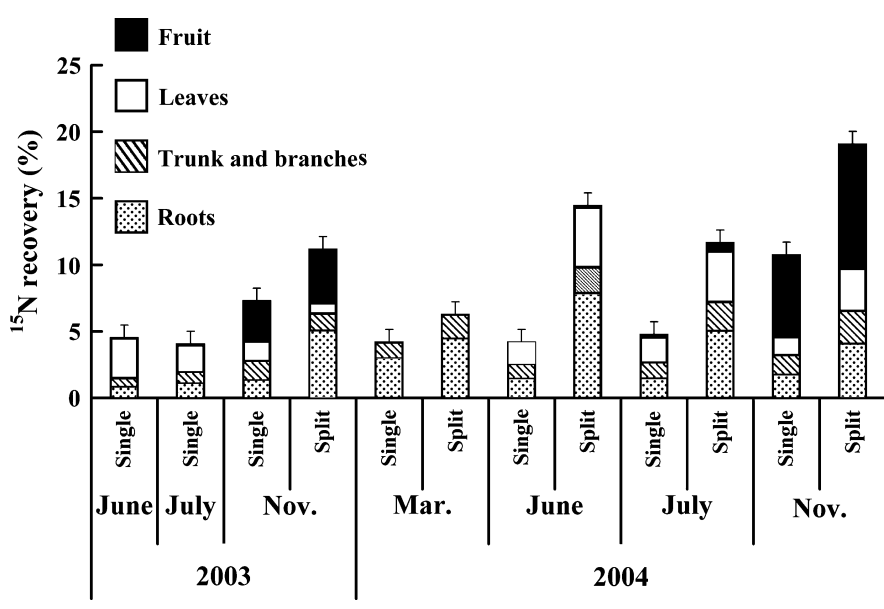

Fig. 3. Recovery of ${ }^{15} \mathrm{~N}$ by 'Pawnee' pecan tree components from a single prebudbreak (10 Mar. 2003) application with ${ }^{15} \mathrm{~N}$-enriched $\mathrm{NH}_{4}{ }^{15} \mathrm{NO}_{3}$ or a split application in March followed by ${ }^{15} \mathrm{~N}$-enriched $\mathrm{NH}_{4}{ }^{15} \mathrm{NO}_{3}$ applied at rapid fruit development (28 July 2003). Vertical bars are the sE for the total ${ }^{15} \mathrm{~N}$ recovered.

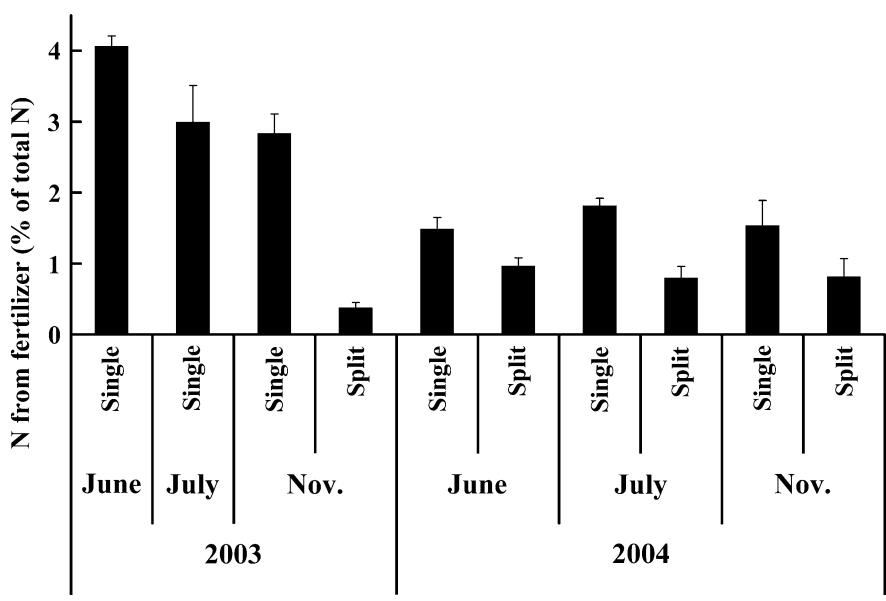

Fig. 4. Influence of a single prebudbreak (10 Mar. 2003) application with ${ }^{15} \mathrm{~N}$ enriched $\mathrm{NH}_{4}{ }^{15} \mathrm{NO}_{3}$ or a split application in March followed by ${ }^{15} \mathrm{~N}$-enriched $\mathrm{NH}_{4}{ }^{15} \mathrm{NO}_{3}$ applied at rapid fruit development (28 July 2003) on the nitrogen derived from fertilizer in 'Pawnee' pecan leaves. Vertical bars are the SE.

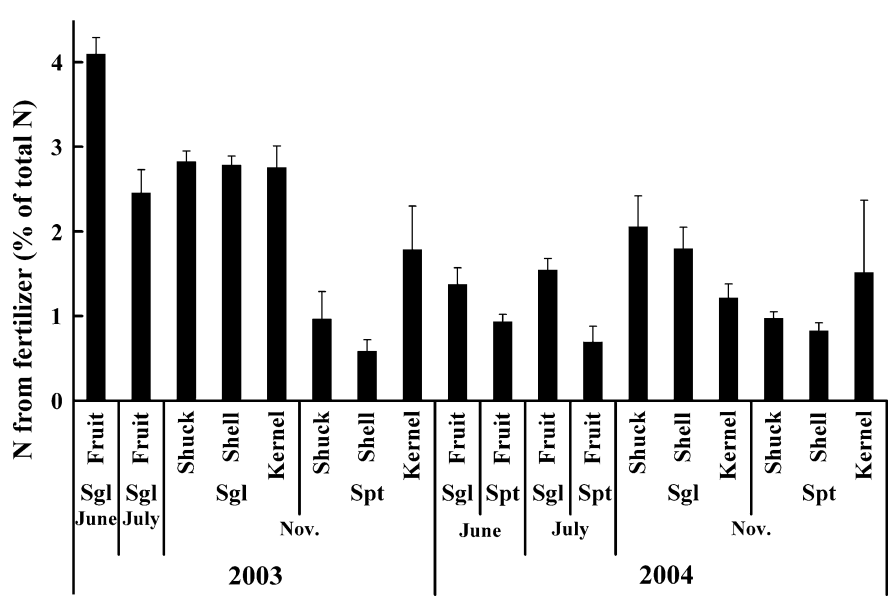

Fig. 5. Influence of a single (Sgl) prebudbreak (10 Mar. 2003) application with ${ }^{15} \mathrm{~N}$-enriched $\mathrm{NH}_{4}{ }^{15} \mathrm{NO}_{3}$ or a split (Spt) application in March followed by ${ }^{15} \mathrm{~N}$ enriched $\mathrm{NH}_{4}{ }^{15} \mathrm{NO}_{3}$ applied at rapid fruit development (28 July 2003) on the nitrogen derived from fertilizer in 'Pawnee' pecan fruit. Vertical bars are the SE.
November, $3 \%$ of the PBB-applied ${ }^{15} \mathrm{~N}$ was in fruit (shuck, shell, and kernel) compared with $4 \%$ when applied at RFD. Of the fertilizer $\mathrm{N}$ recovered during the first year, $41 \%$ and $36 \%$ was in the fruit from the PBB and RFD applications, respectively. The shuck contained $26 \%$ and $22 \%$ of the recovered $\mathrm{N}$ from the PBB and RFD treatments, respectively, potentially recycling in the orchard system via decomposition. Thus, $\approx 15 \%$ of the recovered fertilizer $\mathrm{N}$ was removed in the nuts during harvest.

The shuck, shell, and kernel of trees receiving ${ }^{15} \mathrm{~N}$-enriched fertilizer PBB had similar fractions of NDF the first year, $\approx 2.8 \%$ of total $\mathrm{N}$ (Fig. 5). The ratio of current-season absorbed and stored $\mathrm{N}$ transported to fruit was apparently similar throughout fruit development (i.e., fruit tissue developing at different times had similar percentages of NDF). Substantially more of the fruit's $\mathrm{N}$ was derived from storage reserves $(\approx 97 \%)$. When ${ }^{15} \mathrm{~N}$-enriched fertilizer was applied at RFD, the highest percentage of NDF was in the kernel, followed by shuck and shell tissue. Fruit were nearing full size, and rapid cotyledon development began $\approx 3$ weeks later when applied at RFD. The result was preferential $\mathrm{N}$ transport to developing kernels rather than to other fruit parts.

In Nov. 2003, senescing foliage of trees that received PBB ${ }^{15} \mathrm{~N}$-enriched fertilizer had $21 \%$ of the recovered $\mathrm{N}$ and those treated at RFD had $7 \%$ (Fig. 3). About $2.75 \%$ of the leaf $\mathrm{N}$ present in November was recovered from the PBB N application, whereas $0.5 \%$ was recovered from the RFD application (Fig. 4). Recovered N in leaves decreased $27 \%$ between July and Nov. (Fig. 3), indicating that $\mathrm{N}$ was being mobilized to developing fruit and perennial tissue, with possibly some losses to the environment. However, substantial $\mathrm{N}$ remained in the leaves when they senesced, indicating that trees were either not $\mathrm{N}$ stressed or that relatively little $\mathrm{N}$ was remobilized from senescing foliage under conditions of this study.

The timing of $\mathrm{N}$ application affected $\mathrm{N}$ accumulation by roots (Fig. 3). More recovered $\mathrm{N}$ was located in Novembersampled roots when the ${ }^{15} \mathrm{~N}$-enriched fertilizer was applied at RFD in July as part of a split application than when as a single PBB application in March. The small roots had more NDF in November than did the large roots, regardless of application time (Fig. 6). In November, NDF was greater in the bark, wood, and current-season shoots than the RFD split-application treatment, reflecting a larger application rate and longer distribution time.

Differences in N recovery between leaf fall in Nov. 2003 and bud swell in Mar. 2004 indicate that trees receiving a single PBB treatment in March absorbed substantial amounts of N during winter (Fig. 3). Recovered $\mathrm{N}$ increases $\approx 50 \%$ between fall defoliation and spring bud swell in the perennial tree parts. Evidence for dormant season $\mathrm{N}$ absorption was also indicated by increased NDF in roots $\geq 1 \mathrm{~cm}$ diameter of trees receiving $\mathrm{N}$ PBB (Fig. 6). Essentially no difference occurred in N recovery in perennial tissue between Nov. 2003 and Mar. 2004 when trees received ${ }^{15} \mathrm{~N}$-enriched fertilizer at RFD in the split $\mathrm{N}$ application, indicating no detectable winter $\mathrm{N}$ absorption (Fig. 3 ). Nitrogen absorption by pecan during the dormant season has been reported by others (Acuña-Maldonado et al., 2003; Smith and Waugh, 1938). This result suggests that $\mathrm{N}$ demand was satisfied before leaf fall when a portion of the $\mathrm{N}$ was applied at RFD, whereas demand remained unsatisfied until dormancy when applied only $\mathrm{PBB}$. The $\mathrm{N}$ shortfall appears to trigger dormant-season root $\mathrm{N}$ absorption in preparation for the next growing season. 

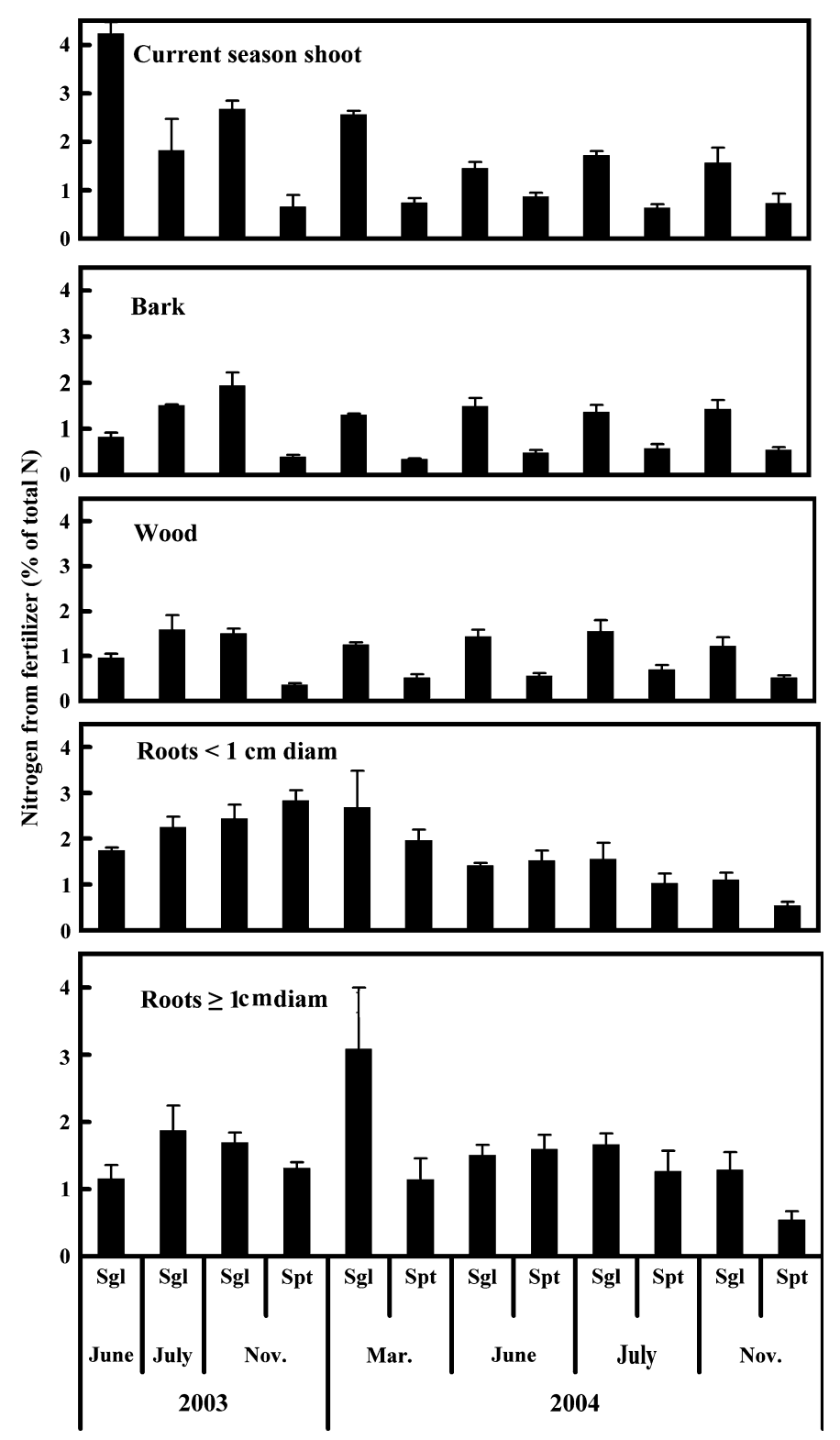

Fig. 6. Influence of a single (Sgl) prebudbreak (10 Mar. 2003) application with ${ }^{15} \mathrm{~N}$-enriched $\mathrm{NH}_{4}{ }^{15} \mathrm{NO}_{3}$ or a split (Spt) application in March followed by ${ }^{15} \mathrm{~N}$-enriched $\mathrm{NH}_{4}{ }^{15} \mathrm{NO}_{3}$ applied at rapid fruit development (28 July 2003) on the nitrogen derived from fertilizer in perennial 'Pawnee' pecan tree parts. Vertical bars are the SE.

In June of the second year, little additional $\mathrm{N}$ was recovered from the previous year's PBB application (Fig. 3). Redistribution of $\mathrm{N}$ stored in perennial tissue during March to leaves was evident in June. However, $\mathrm{N}$ absorption, occurring primarily after July, increased $\mathrm{N}$ recovery to $12 \%$ by November of the second year in trees with a single PBB $\mathrm{N}$ application. In contrast, $\mathrm{N}$ absorption was evident by June of the second year when ${ }^{15} \mathrm{~N}$-enriched fertilizer was applied at RFD the previous year as part of a split-application strategy. In November of the second year, $19 \%$ of the previous RFD application had been recovered. Ninety-three percent more $\mathrm{N}$ was absorbed from the PBB application at $1.689 \mathrm{~g} \cdot \mathrm{cm}^{-2}$ cross-sectional trunk area $\mathrm{N}$ than the RFD application at $0.506 \mathrm{~g} \cdot \mathrm{cm}^{-2}$ cross-sectional trunk area $\mathrm{N}$ by Nov. 2004.
Fruit contained $6 \%$ and $9 \%$ of the recovered $\mathrm{N}$ during November of the second year for single PBB application and split application at RFD, respectively (Fig. 3), thus representing $57 \%$ and $49 \%$ of the total $\mathrm{N}$ recovered from applied fertilizer by the end of the second year for PBB and RFD treatments, respectively. The NDF decreased most from the shuck followed by the shell and lastly by the kernel when trees received a PBB application (Fig. 5). This result indicates that $\mathrm{N}$ from the previous season's PBB (Mar. 2003) application was being depleted in 2004 because later-developing fruit parts had less NDF. In contrast, the kernel had more NDF than the shuck and shell from the split application at RFD. The kernel develops last, indicating that ${ }^{15} \mathrm{~N}$-enriched fertilizer applied at RFD in July 2003 remained in the soil and was absorbed during the latter part of the 2004 growing season. Absorption rather than mobilization from storage pools was indicated because NDF would either follow the declining pattern evident in fruit parts of the PBB treatment or NDF would be similar among fruit parts if from stored $\mathrm{N}$.

During the second year, NDF in perennial parts averaged $1.2 \%$ for the PBB-applied ${ }^{15} \mathrm{~N}$-enriched fertilizer treatment. Percentages were similar among the perennial parts (Fig. 6). The fraction averaged $0.5 \%$ from the RFD treatment, with similar percentages in the various perennial parts.

Three studies on pecan, all in the lower Mesilla Valley of New Mexico, reported $\mathrm{N}$ recovery using ${ }^{15} \mathrm{~N}$-enriched fertilizer. Recovery of broadcast fertilizer ranged from $19.5 \%$ to $27 \%$ (Kraimer et al., 2001, 2004; Rey et al., 2006). In this study, recovery was lower, ranging from $12 \%$ for the PBB treatment to $19 \%$ for the RFD treatment as part of a split-application strategy. The different recoveries may be associated with differences in crop culture, crop load, or calculations used to derive recoveries. For instance, the test orchard in New Mexico was flood-irrigated, rainfall was rare, and orchard floors were clean-cultivated by disking; additionally, tree $\mathrm{N}$ demand characteristics likely differed due to differences in pruning practices, light environment, and various biotic and abiotic stresses. It is also noteworthy that $\mathrm{N}$ was applied six times in small amounts in one study (Kraimer et al., 2001), and recovery from late-season $\mathrm{N}$ applications was tested in another study (Rey et al., 2006). In contrast, the present study depended on natural rainfall and the orchard floor was not disk-cultivated and had grass cover before the study but was maintained vegetationfree during the study with herbicide. Other differences were in soil texture, soil $\mathrm{pH}$, depth to water table, $\mathrm{N}$ form $\left[\left({ }^{15} \mathrm{NH}_{4}\right)_{2} \mathrm{SO}_{4}\right.$ vs. $\mathrm{NH}_{4}{ }^{15} \mathrm{NO}_{3}$ ], and tree characteristics (i.e., rootstock, cultivar, physiological age, low crop year). Another major difference is that allometric equations used to estimate tree component weights in the New Mexico studies are derived for black oak (Quercus velutina Lam.) (King and Schnell, 1972), whereas the present study used equations recently developed for pecan (Smith and Wood, 2006). When considered together, these studies indicate that, under widely varying conditions, recovery of applied $\mathrm{N}$ in pecan ranges from $12 \%$ to $27 \%$. This recovery percentage is less than that reported for certain other tree species (Weinbaum, 1979).

Recovery of applied $\mathrm{N}$ was lower when applied as a single PBB treatment in March than at RFD in July as part of a splitapplication strategy, perhaps because of a larger application amount at PBB or greater demand during RFD. Two hundred ten percent more $\mathrm{N}$ was applied $\mathrm{PBB}$ than $\mathrm{RFD}$, resulting in $118 \%$ more absorption in the current year and $93 \%$ during the 
second year. Both approaches reflect application strategies followed by United States pecan producers and by many growing other fruit crops. Nitrogen demand and absorption appear to be greatest during rapid growth and leaf expansion in the spring (Acuña-Maldonado et al., 2003). Recovery of applied $\mathrm{N}$ should increase if spring $\mathrm{N}$ rates are lower. Nitrogen recovery was greater when applied at RFD in July. This result may be associated with a lower application rate than at PBB or with demand created by rapidly developing cotyledons within nuts. Others have reported rapid absorption of $\mathrm{N}$ during cotyledon development (Kraimer et al., 2004; Rey et al., 2006). No studies have reported yield benefits or reduction in alternate bearing as a consequence of summer vs. fall $\mathrm{N}$ applications [Acuña-Maldonado et al., 2003; E.A. Herrera, personal communications cited in Rey et al. (2006); Smith et al. (2004)]. Frequently, N must be withheld several years before there is a noticeable impact on pecan production (Smith, 2002; Worley, 1974, 1990). This study and others (Kraimer et al., 2004; Rey et al., 2006) illustrate that applied $\mathrm{N}$ was rapidly absorbed and transported to the developing fruit and leaves. However, in the present study, most of the $\mathrm{N}$ in fruit and foliage originated from endogenous $\mathrm{N}$ pools, indicating that the test orchard was under a good state of $\mathrm{N}$ management. This may explain why $\mathrm{N}$ application time in well $\mathrm{N}$-managed commercial orchards may not have a substantial effect on nut production (i.e., trees rely primarily on endogenous $\mathrm{N}$ pools, and currentyear absorption accounts for a small portion of $\mathrm{N}$ demand). These studies illustrate the importance of maintaining an annual $\mathrm{N}$ fertility program, as much of the used $\mathrm{N}$ nutrition is derived from past years' accumulations. Additional research is needed regarding the relationship of endogenous tree pools of reduced, organically bound $\mathrm{N}$ to production characteristics, such as alternate bearing intensity, flowering, and kernel quality.

\section{Literature Cited}

Acuña-Maldonado, L.E., M.W. Smith, N.O. Maness, B.S. Cheary, and B.L. Carroll. 2003. Influence of nitrogen application time on nitrogen absorption, partitioning, and yield of pecan. J. Amer. Soc. Hort. Sci. 128:155-162.

Allen, S.C., S. Jose, P.K.R. Nair, B.J. Brecke, and C.L. Ramsey. 2004. Competition for ${ }^{15} \mathrm{~N}$-labeled fertilizer in pecan (Carya illinoensis $\mathrm{K}$. Koch)-cotton (Gossypium hirsutum L.) alley cropping system in the southern United States. Plant Soil 263:151-164.

Brown, P.H., S.A. Weinbaum, and G.A. Picchioni. 1995. Alternate bearing influences annual nutrient consumption and the total nutrient content of mature pistachio trees. Trees Structure Function 9:158-164. Goff, B., M. Nesbitt, and C. Browne. 2001. Late season fertilization: an exciting new development for the pecan industry. Proc. Southeastern Pecan Growers' Assn. 94:91-93.

Horowitz, W. 1980. Official methods of analysis of the association of analytical chemists. 13th ed. Assn. Offic. Anal. Chemists, Washington, D.C.

King, W.W. and R.L. Schnell. 1972. Biomass estimates of black oak tree components. Tennessee Valley Authority Div. For., Fisheries, and Wildlife Mgt. Tech. Note B1.

Kizer, M., J.D. Carlson, and A. Sutherland. 2005. Evapotranspiration product description27 June 2007. <http://agweather.mesonet.ou.edu/ info/Evapotranspiration_Product_Description.pdf $>$.
Kraimer, R.A., W.C. Lindemann, and E.A. Herrera. 2001. Distribution of ${ }^{15} \mathrm{~N}$-labeled fertilizer applied to pecan: a case study. HortScience 36:308-312.

Kraimer, R.A., W.C. Lindemann, and E.A. Herrera. 2004. Recovery of late-season ${ }^{15} \mathrm{~N}$-labeled fertilizer applied to pecan. HortScience 39:256-260.

Picchioni, G.A., P.H. Brown, S.A. Weinbaum, and T.T. Muraoka. 1997. Macronutrient allocation to leaves and fruit of mature, alternate-bearing pistachio trees: magnitude and seasonal patterns at the whole-canopy level. J. Amer. Soc. Hort. Sci. 122: 267-274.

Rey, A., W.C. Lindemann, and M.D. Remmenga. 2006. Recovery of ${ }^{15} \mathrm{~N}$ fertilizer applied at different stages of pecan kernel fill. HortScience 41:794-798.

Rosecrance, R.C., S.A. Weinbaum, and P.H. Brown. 1996. Assessment of nitrogen, phosphorus, and potassium uptake capacity and root growth in mature alternate-bearing pistachio (Pistacia vera) trees. Tree Physiol. 16:949-956.

Rosecrance, R.C., S.A. Weinbaum, and P.H. Brown. 1998. Alternate bearing affects nitrogen, phosphorus, potassium and starch storage pools in mature pistachio trees. Ann. Bot. (Lond.) 82: 463-470.

Smith, C.L. and J.G. Waugh. 1938. Seasonal variations in the carbohydrate and nitrogen content of roots of bearing pecan trees. J. Agr. Res. 57:449-460.

Smith, M.W. 2002. Influence of nitrogen application time on nitrogen absorption, partitioning and yield of pecan. Oklahoma Pecan Growers' Assn. 72:40-41.

Smith, M.W., P.L. Ager, and D.S.W. Endicott. 1985. Effect of nitrogen and potassium on yield, growth, and leaf elemental concentration of pecan. J. Amer. Soc. Hort. Sci. 110:446-450.

Smith, M.W., B.L. Carroll, and B.S. Cheary. 2004. Response of pecan to nitrogen rate and nitrogen application time. HortScience 39:14121415.

Smith, M.W. and B.W. Wood. 2006. Pecan tree biomass estimates. HortScience 41:1286-1291.

Stein, L.A. and J.W. Worthington. 1997. Water management, p. V9V20. In: G.R. McEachern and L.A. Stein (eds.). Texas pecan handbook. Texas Agr. Ext. Serv., College Station, TX.

Taylor, R.W. 1930. Influence of fertilizer treatments on yield and quality of pecans. Proc. Natl. Pecan Assn. Bul. 29:18-22.

von Broembsen, S. and P. Mulder. 2005. Commercial pecan disease and insect control-2006. Okla. Coop. Ext. Ser. CR-6209.

Weinbaum, S.A. 1979. Timing of nitrogen application in deciduous fruit tree plantings. Almond Facts (Calif. Almond Growers) 44: 34-36.

Weinbaum, S.A., G.A. Picchioni, T.T. Maraoka, P.H. Brown, and L. Ferguson. 1994. Nitrogen usage, accumulations of carbon and nitrogen reserves, and the capacity for labeled fertilizer nitrogen and boron uptake varies during the alternate-bearing cycle in pistachio. J. Amer. Soc. Hort. Sci. 119:24-31.

Weinbaum, S.A. and C. Van Kessel. 1998. Quantitative estimates of uptake and internal cycling of ${ }^{14} \mathrm{~N}$-labeled fertilizer in mature walnut trees. Tree Physiol. 18:795-801.

Wood, B.W. 2001. Managing nitrogen in pecan orchards. Proc. Southeastern Pecan Growers' Assn. 94:153-159.

Worley, R.E. 1974. Effect of N, P, K, and lime on yield, nut quality, tree growth, and leaf analysis of pecan (Carya illinoensis W.). J. Amer. Soc. Hort. Sci. 99:49-57.

Worley, R.E. 1990. Long-term performance of pecan trees when nitrogen application is based on prescribed threshold concentrations in leaf tissue. J. Amer. Soc. Hort. Sci. 115:745-749. 